\title{
Removal of Organic Matter from Landfill Leachate by Advanced Oxidation Processes: A Review
}

\author{
Wei Li, ${ }^{1}$ Qixing Zhou, ${ }^{1}$ and Tao Hua ${ }^{1,2}$ \\ ${ }^{1}$ Key Laboratory of Pollution Process and Environmental Criteria (Ministry of Education), \\ College of Environmental Science and Engineering, Nankai University, Tianjin 300071, China \\ ${ }^{2}$ TEDA Environmental Protection Co. Ltd., Tianjin 300350, China \\ Correspondence should be addressed to Qixing Zhou, zhouqx@nankai.edu.cn \\ Received 15 January 2010; Accepted 12 April 2010 \\ Academic Editor: Josiane Nikiema
}

Copyright () 2010 Wei Li et al. This is an open access article distributed under the Creative Commons Attribution License, which permits unrestricted use, distribution, and reproduction in any medium, provided the original work is properly cited.

In most countries, sanitary landfill is nowadays the most common way to eliminate municipal solid wastes (MSWs). However, sanitary landfill generates large quantity of heavily polluted leachate, which can induce ecological risk and potential hazards towards public health and ecosystems. The application of advanced oxidation processes (AOPs) including ozone-based oxidation, Fenton oxidation, electrochemical oxidation, and other AOPs to treatment of landfill leachate was reviewed. The treatment efficiency in term of chemical oxygen demand (COD) of various AOPs was presented. Advantages and drawbacks of various AOPs were discussed. Among the AOPs reviewed, Fenton process should be the best choice, not only because it can achieve about $49 \sim 89 \%$ of COD removal with COD ranging from 837 to $8894 \mathrm{mg} / \mathrm{L}$, but also because the process is cost-effective and simple in technological aspect, there is no mass transfer limitation (homogeneous nature) and both iron and hydrogen peroxide are nontoxic.

\section{Introduction}

Due to rapid economic development in recent years, the excessive generation of municipal solid wastes (MSWs) has been identified as one of the most serious environmental problems in the world which needs to be addressed urgently for environmental protection. Up to $95 \%$ total MSW collected worldwide is disposed using the landfilling method [1]. After landfilling, solid waste undergoes a series of physicochemical and biological changes. Consequently, the degradation of the organic fraction of the wastes in combination with percolating rainwater leads to the generation of a highly contaminated liquid called "leachate". Leachate may contain large amount of organic matter (biodegradable, but also refractory to be biodegraded), ammonia-nitrogen, heavy metals, and chlorinated organic compounds and inorganic salts.

The characteristics of landfill leachate are affected by many factors, such as age, precipitation, weather variation, and waste types and compositions. In particular, the composition of landfill leachate varies greatly depending on the age of the landfill [2]. According to the landfill age, the leachate can be classified into three types: young, intermediate, and old, and the relationship of the characteristics of landfill leachate versus the age of landfill is summarized in Table $1[3,4]$. The young landfill leachate is commonly characterized by high biochemical oxygen demand (BOD) (4000-13,000 mg/L) and chemical oxygen demand (COD) (30,000-60,000 mg/L), moderately high content of ammonium nitrogen $(500-2000 \mathrm{mg} / \mathrm{L})$, high ratio of BOD/COD (ranging from 0.4 to 0.7 ), and low $\mathrm{pH}$ values (as low as 4.0 ), with biodegradable volatile fatty acids (VFAs) appear to be its major constituents [5]. With an increase in the landfill age and decomposing of VFAs in the landfill leachate by anaerobe bacteria over a period of 10 years, the old leachates are catalogued as stabilized and characterized by a relatively low COD ( $<4000 \mathrm{mg} / \mathrm{L})$, slightly basic $\mathrm{pH}$ (7.5-8.5), low biodegradability $\left(\mathrm{BOD}_{5} / \mathrm{COD}<0.1\right)$, and high molecular weight compounds (humic substances) [6].

Toxicity analysis carried out using various test organisms such as Vibrio fisheri, Daphnia similes, Artemia salina, and Brachydanio rerio has confirmed that the potential dangers 
TABLE 1: Landfill leachate classification versus age $[3,4]$.

\begin{tabular}{|c|c|c|c|}
\hline Type of leachate & Young & Intermediate & Old \\
\hline Age (years) & $<5$ & $5-10$ & $>10$ \\
\hline $\mathrm{pH}$ & $<6.5$ & $6.5-7.5$ & $>7.5$ \\
\hline $\mathrm{COD}(\mathrm{mg} / \mathrm{L})$ & $>10,000$ & $4000-10,000$ & $<4000$ \\
\hline $\mathrm{BOD}_{5} / \mathrm{COD}$ & $0.5-1.0$ & $0.1-0.5$ & $<0.1$ \\
\hline Organic compounds & $80 \%$ volatile fatty acids (VFA) & $5 \%-30 \%$ VFA + humic and fulvic acid & Humic and fulvic acids \\
\hline Ammonia nitrogen $(\mathrm{mg} / \mathrm{L})$ & $<400$ & N.A & $>400$ \\
\hline TOC/COD & $<0.3$ & $0.3-0.5$ & $>0.5$ \\
\hline Kjeldahl nitrogen (g/L) & $0.1-0.2$ & N.A & N.A \\
\hline Heavy metals (mg/L) & Low to medium & Low & Low \\
\hline Biodegradability & Important & Medium & Low \\
\hline
\end{tabular}

of landfill leachate [7-10] and the necessity to treat is so as to meet the standards for discharge in receiving waters. Laboratory studies to determine the effectiveness of various biological, physical, and chemical treatment processes on landfill leachate have been investigated since the early 1970s. Biological treatment processes, including anaerobic and aerobic processes, are quite effective for leachate generated in the early stage with a high $\mathrm{BOD}_{5} / \mathrm{COD}$. However, they generally fail to treat a leachate with a rather low $\mathrm{BOD}_{5} / \mathrm{COD}$, or high concentration of toxic metals [11]. Hence, physicalchemical processes are mostly used for pretreatment or full treatment for this type of landfill leachate.

Among the various types of physical-chemical treatments, advanced oxidation processes (AOPs) has been reported as one of the most effective method to degrade a variety of refractory compounds in landfill leachate [12]. This can be attributed to the role of a highly reactive radical intermediate such as hydroxyl radical $(\bullet \mathrm{OH})$ as an oxidant. The radicals can be produced in ozone oxidation, Fenton oxidation, and electrochemical oxidation systems.

With an oxidation potential $\left(E^{0}\right)$ of $2.80 \mathrm{~V}$ (Table 2), the - $\mathrm{OH}$ radical can rapidly degrade recalcitrant organics such as aromatic, chlorinated, and phenolic compounds [13]. Once a reaction of the free radical is initiated by ozone or $\mathrm{H}_{2} \mathrm{O}_{2}$, a series of oxidation reactions occurs in the solution and the radicals rapidly react with most of the target compounds. The kinetic rate of AOPs depends on the concentration of radicals and pollutants, temperature as well as the presence of scavengers such as bicarbonate ion [14].

\section{Treatment of Landfill Leachate via AOPs}

2.1. Ozone-Based Oxidation Processes. Ozonation processes are attractive means for the treatment of landfill leachates due to the high oxidative power that ozone possesses [15]. As one of the most powerful oxidants with an oxidation potential $\left(E^{0}\right)$ of $2.08 \mathrm{~V}$ (Table 2), ozonation alters the molecular structure of refractory organic compounds in landfill leachate, turning them into compounds that are easily assimilated biologically [16].

Depending on the $\mathrm{pH}$ values, which play major roles in the ozone decomposition, ozone oxidation follows the two
TABLE 2: Oxidizing potential of some oxidizing agents [13].

\begin{tabular}{lc}
\hline Type of oxidizing agents & Oxidation potential $\left(\mathrm{E}^{0}\right)(\mathrm{V})$ \\
\hline Fluorine & 3.06 \\
Hydroxyl radical & 2.80 \\
Oxygen (atomic) & 2.42 \\
Ozone & 2.08 \\
Hypochlorite & 1.49 \\
Hydrogen peroxide & 1.78 \\
Chlorine & 1.36 \\
Chlorine dioxide & 1.27 \\
Oxygen (molecular) & 1.23
\end{tabular}

main pathways: either a direct electrophilic attack of the ozone molecule to the recalcitrant pollutants or a generation of $\bullet \mathrm{OH}$ radicals due to the ozone decomposition process and followed by a subsequent attack of the radicals on the pollutants [17].

At an acidic $\mathrm{pH}$ range, ozone undergoes selective electrophilic attack on the specific part of the organic compounds that have $\mathrm{C}=\mathrm{C}$ bonds and/or aromatic ring [18] and decomposes them into carboxylic acid and aldehydes as the end products [19]. When exposed to the $\mathrm{pH}$ values ranging from 8.0 to 9.0 , in the presence of $\mathrm{OH}^{-}$ions, the hydroxide ion reacts with ozone to yield superoxide anion radicals $\left(\cdot \mathrm{O}_{2}{ }^{-}\right)$, which in their turn are involved in a series of reactions as follows:

$$
\text { Initiation } \mathrm{O}_{3}+\mathrm{OH}^{-} \longrightarrow \cdot \mathrm{O}_{2}^{-}+\mathrm{HO}_{2} \bullet \text {, }
$$

Radical chain-reaction $\mathrm{O}_{3}+\bullet \mathrm{O}_{2}{ }^{-} \longrightarrow \cdot \mathrm{O}_{3}{ }^{-1}+\mathrm{O}_{2}$,

$$
\begin{gathered}
\bullet \mathrm{O}_{3}{ }^{-1} \longrightarrow \cdot \mathrm{OH}+\mathrm{O}_{2}, \\
\bullet \mathrm{OH}+\mathrm{O}_{3} \longrightarrow \mathrm{HO}_{2} \bullet+\mathrm{O}_{2} \longrightarrow \mathrm{HO}_{4} \bullet \\
\mathrm{HO}_{4} \bullet \longrightarrow \cdot \mathrm{O}_{2}{ }^{-}+\mathrm{O}_{2}, \\
\mathrm{HO}_{2} \bullet \longrightarrow \cdot \mathrm{O}_{2}^{-}+\mathrm{H}^{+},
\end{gathered}
$$$$
\text { Termination } \mathrm{HO}_{4} \bullet+\mathrm{HO}_{4} \bullet \longrightarrow \mathrm{H}_{2} \mathrm{O}_{2}+2 \mathrm{O}_{3} \text {. }
$$

Overall, $1 \mathrm{~mol}$ of $\mathrm{O}_{3}$ yields $1 \mathrm{~mol}$ of $\bullet \mathrm{OH}$. 
When $\mathrm{pH}$ is higher than 9.0, oxidation through the formation of $\bullet \mathrm{OH}$ radical is limited by the presence of ozoneresistant compounds or $\bullet \mathrm{OH}$ radical scavengers. Under such condition, bicarbonate ions are converted to carbonate ions, which are the scavengers for $\bullet \mathrm{OH}$ radicals that slow down the kinetic rate of the oxidation reaction [17]. The corresponding equation is listed as follows:

$$
\bullet \mathrm{OH}+\mathrm{P} \longrightarrow \text { end products, }
$$

where $\mathrm{P}$ represents the scavenger of hydroxyl radicals such as $\mathrm{HCO}_{3}{ }^{-}$and $\mathrm{CO}_{3}{ }^{2-}$. Some examples of the reactions are presented as follows:

$$
\begin{gathered}
\bullet \mathrm{OH}+\mathrm{CO}_{3}^{2-} \longrightarrow \mathrm{OH}^{-}+\mathrm{CO}_{3} \bullet^{-} \\
\bullet \mathrm{OH}+\mathrm{HCO}_{3}^{-} \longrightarrow \mathrm{OH}^{-}+\mathrm{HCO}_{3} \bullet
\end{gathered}
$$

As a single process, oxidation with ozone is not considered as very effective due to the complexity of leachate composition, high ozone doses are often required and the respective reaction may take longer time, rendering this process economically unfavorable [20]. Ozone processes can be made more effective by employing UV irradiation $\left(\mathrm{O}_{3} / \mathrm{UV}\right)$ or the addition of hydrogen peroxide $\left(\mathrm{O}_{3} / \mathrm{H}_{2} \mathrm{O}_{2}\right)$. UV and $\mathrm{H}_{2} \mathrm{O}_{2}$ initiate a series of radical reactions that enhance ozone decomposition to yield $\bullet \mathrm{OH}$ [21]. In the $\mathrm{O}_{3} / \mathrm{UV}$ process, UV irradiation not only activates the ozone molecules by absorbing the UV light at $254 \mathrm{~nm}$, but also makes other organic molecules susceptible to the oxidation process [22]. The initial step of the radical mechanism in this process is the direct photolysis of the ozone to produce $\bullet \mathrm{OH}$, as shown in the following reactions [23]:

$$
\begin{gathered}
\mathrm{O}_{3}+\mathrm{H}_{2} \mathrm{O}+\mathrm{hv} \longrightarrow \mathrm{H}_{2} \mathrm{O}_{2}+\mathrm{O}_{2}, \\
\mathrm{H}_{2} \mathrm{O}_{2}+\mathrm{hv} \longrightarrow 2 \cdot \mathrm{OH} .
\end{gathered}
$$

And the net reaction is

$$
\mathrm{O}_{3}+\mathrm{H}_{2} \mathrm{O}+\mathrm{hv} \longrightarrow 2 \cdot \mathrm{OH}+\mathrm{O}_{2} .
$$

On the other hand, in the $\mathrm{O}_{3} / \mathrm{H}_{2} \mathrm{O}_{2}$ system, the addition of $\mathrm{H}_{2} \mathrm{O}_{2}$ can accelerate the decomposition of ozone and subsequently enhance the production of $\bullet \mathrm{OH}$ radicals, as (6):

$$
2 \mathrm{O}_{3}+\mathrm{H}_{2} \mathrm{O}_{2} \longrightarrow 2 \cdot \mathrm{OH}+3 \mathrm{O}_{2} .
$$

The reactions involved are very complex in the systems, since the organic compounds can be degraded either by direct ozonation, photolysis reaction, or $\bullet \mathrm{OH}$ oxidation [17].

Performance of $\mathrm{O}_{3}, \mathrm{O}_{3} / \mathrm{H}_{2} \mathrm{O}_{2}$, and $\mathrm{O}_{3} / \mathrm{UV}$ process can be evaluated thanks to key parameters (COD, BOD, BOD/COD, and oxidant dose) summarized in Table 3 . As previously mentioned, ozonation as a single process was not considered as very effective (COD reduction is about $15-50 \%)[15,16$, 24-29]. Thus, most researchers used ozonation process as pretreatment before biological treatment or tertiary treatment prior to discharge in the environment. COD reduction can be greatly enhanced via combining oxidants $\left(\mathrm{H}_{2} \mathrm{O}_{2} / \mathrm{O}_{3}\right)$ (Table 3). Wable et al. [28] and Schulte et al. [30] reported the efficiency of organic matter removal can be up to $95 \%$ and $97 \%$, respectively. However, adding an irradiation system ( $\mathrm{UV} / \mathrm{H}_{2} \mathrm{O}_{2}$ ) was not as efficient as $\mathrm{H}_{2} \mathrm{O}_{2} / \mathrm{O}_{3}$ system, with COD reduction at a range between $40 \%$ and $63 \%$.

The common drawback of ozone-based oxidation is the high demand of oxidant $\left(\mathrm{O}_{3}\right.$ or $\left.\mathrm{H}_{2} \mathrm{O}_{2}\right)$ and the electrical energy used by UV lamps, which results in rather high treatment costs. However, ozone-based oxidation can improve the biodegradability of landfill leachate (Table 3 ). Using ozonebased oxidation as pretreatment of biological treatment can lower the cost.

2.2. Fenton Oxidation. Fenton process has been extensively studied in recent years, and analyses indicate Fenton process to be one of the most cost-effective alternatives for this application [37]. In the Fenton process, hydrogen peroxide is added to wastewater in presence of ferrous salts, generating species that are strongly oxidative with respect to organic compounds. $\bullet \mathrm{OH}$ is traditionally regarded as the key oxidizing species in the Fenton processes. The classical Fenton free radical mechanism in the absence of organic compounds mainly involves the sequence of reactions below [38]:

$$
\begin{gathered}
\mathrm{Fe}^{2+}+\mathrm{H}_{2} \mathrm{O}_{2} \longrightarrow \mathrm{Fe}^{3+}+\bullet \mathrm{OH}+\mathrm{OH}^{-} \\
\mathrm{Fe}^{3+}+\mathrm{H}_{2} \mathrm{O}_{2} \longrightarrow \mathrm{Fe}^{2+}+\mathrm{HO} \bullet 2+\mathrm{H}^{+} \\
\bullet \mathrm{OH}+\mathrm{H}_{2} \mathrm{O}_{2} \longrightarrow \mathrm{HO} \bullet_{2}+\mathrm{H}_{2} \mathrm{O} \\
\bullet \mathrm{OH}+\mathrm{Fe}^{2+} \longrightarrow \mathrm{Fe}^{3+}+\mathrm{OH}^{-} \\
\mathrm{Fe}^{3+}+\mathrm{HO}_{2} \longrightarrow \mathrm{Fe}^{2+}+\mathrm{O}_{2} \mathrm{H}^{+} \\
\mathrm{Fe}^{2+}+\mathrm{HO}_{2}+\mathrm{H}^{+} \longrightarrow \mathrm{Fe}^{3+}+\mathrm{H}_{2} \mathrm{O}_{2} \\
2 \mathrm{HO} \bullet_{2} \longrightarrow \mathrm{H}_{2} \mathrm{O}_{2}+\mathrm{O}_{2}
\end{gathered}
$$

- $\mathrm{OH}$ radicals are rapidly generated through (7). In the above reactions, iron cycles between $\mathrm{Fe}^{2+}$ and $\mathrm{Fe}^{3+}$, and plays the role of catalyst. The net reaction of (7)-(13) is the decomposition of $\mathrm{H}_{2} \mathrm{O}_{2}$ into water and $\mathrm{O}_{2}$ catalyzed by iron as follows:

$$
2 \mathrm{H}_{2} \mathrm{O}_{2} \longrightarrow 2 \mathrm{H}_{2} \mathrm{O}+\mathrm{O}_{2} \text {. }
$$

Generally speaking, Fenton's oxidation process is composed of four stages including $\mathrm{pH}$ adjustment, oxidation reaction, neutralization and coagulation, and precipitation. The organic substances are removed at two stages of oxidation and coagulation [39]. $\bullet \mathrm{OH}$ radicals are responsible for oxidation, and coagulation is ascribed to the formation of ferric hydroxo complexes [40]. The relative importance of oxidation and coagulation depends primarily on the $\mathrm{H}_{2} \mathrm{O}_{2} / \mathrm{Fe}^{2+}$ ratio. Chemical coagulation predominates at a lower $\mathrm{H}_{2} \mathrm{O}_{2} / \mathrm{Fe}^{2+}$ ratio, whereas chemical oxidation is dominant at higher $\mathrm{H}_{2} \mathrm{O}_{2} / \mathrm{Fe}^{2+}$ ratios [41]. Wang et al. [42] and Lau et al. [43] reported that oxidation and coagulation were responsible for approximately 20 and $80 \%$ of overall COD removal respectively, in Fenton treatment of biologically stabilized leachate. 
TABLE 3: $\mathrm{O}_{3}, \mathrm{O}_{3} / \mathrm{H}_{2} \mathrm{O}_{2}$, and $\mathrm{O}_{3} / \mathrm{UV}$ treatments of leachates (updated from Renou et al. [2]).

\begin{tabular}{|c|c|c|c|c|c|c|c|c|c|c|}
\hline \multicolumn{4}{|c|}{ Initial characteristics of the leachate } & \multirow{2}{*}{$\begin{array}{c}\text { BOD/COD } \\
\text { After } \\
\text { treatment }\end{array}$} & \multicolumn{2}{|c|}{ Removal efficiency (\%) } & \multirow{2}{*}{$\begin{array}{c}\mathrm{O}_{3}(\mathrm{a} . \mathrm{g} / \mathrm{l}) \\
\text { or } \\
\left(\mathrm{b} . \mathrm{gO}_{3} / \mathrm{g}\right. \\
\mathrm{COD})\end{array}$} & \multirow{2}{*}{$\begin{array}{l}\mathrm{H}_{2} \mathrm{O}_{2} / \mathrm{O}_{3} \\
(\mathrm{~g} / \mathrm{g})\end{array}$} & \multirow{2}{*}{$\mathrm{UV}(\mathrm{W})$} & \multirow{2}{*}{ Reference } \\
\hline $\begin{array}{l}\mathrm{COD} \\
(\mathrm{mg} / \mathrm{L})\end{array}$ & $\begin{array}{c}\mathrm{BOD} \\
(\mathrm{mg} / \mathrm{L})\end{array}$ & $\mathrm{pH}$ & $\begin{array}{c}\text { Color } \\
(\mathrm{mgP} \text { tCo/l) }\end{array}$ & & $\mathrm{COD}$ & Color & & & & \\
\hline \multicolumn{11}{|c|}{$\mathrm{O}_{3}$} \\
\hline 6500 & 500 & 8.1 & 12,000 & 0.5 & 15 & 90 & $1.2^{\mathrm{a}}$ & & & [15] \\
\hline 3096 & 130 & 8.2 & 5759 & $0.2-0.3$ & $25-50$ & - & $3.0^{\mathrm{a}}$ & & & {$[16]$} \\
\hline 3460 & 150 & 8.2 & 5300 & - & 48 & 87 & $3.0^{\mathrm{a}}$ & & & [24] \\
\hline $4850 \pm 100$ & $520 \pm 30$ & 8.2 & - & 0.25 & 30 & - & $1.3-1.5^{\mathrm{b}}$ & & & [25] \\
\hline 5000 & 20 & - & 8300 & 0.015 & 33 & 100 & $1.7^{\mathrm{b}}$ & & & [26] \\
\hline 5230 & 500 & 8.7 & - & 0.1 & 27 & - & - & & & [27] \\
\hline 4850 & 10 & - & - & 0.1 & 33 & - & - & & & [29] \\
\hline 895 & 43 & 8.2 & - & 0.14 & 28 & - & $0.76^{\mathrm{b}}$ & & & [31] \\
\hline \multicolumn{11}{|c|}{$\mathrm{O}_{3} / \mathrm{H}_{2} \mathrm{O}_{2}$} \\
\hline 5230 & 500 & 8.7 & - & 0.7 & 48 & 94 & - & $\mathrm{H}_{2} \mathrm{O}_{2}: 2 \mathrm{~g} / \mathrm{L}$ & & [27] \\
\hline 2000 & - & - & - & - & 95 & - & $3.5^{\mathrm{b}}$ & 0.4 & & [28] \\
\hline 600 & - & - & - & - & 92 & - & $3.3^{\mathrm{b}}$ & 0.4 & & \\
\hline 2000 & 160 & 8.4 & - & 0.13 & 92 & - & $1.5^{\mathrm{b}}$ & 0.3 & & [32] \\
\hline - & - & 8 & & - & 97 & - & $2.5^{\mathrm{a}}$ & 2 & & [30] \\
\hline - & - & 8 & & - & 70 & - & & 0.5 & & \\
\hline 1360 & $<5$ & 8.4 & - & 0.32 & 93 & - & $1.5^{\mathrm{b}}$ & 0.3 & & {$[31]$} \\
\hline 480 & 25 & 7.7 & - & 0.13 & 40 & & $0.05-0.5^{\mathrm{b}}$ & $0.25-1$ & & [33] \\
\hline \multicolumn{11}{|c|}{$\mathrm{O}_{3} / \mathrm{UV}$} \\
\hline 1280 & 100 & 2 & - & - & 54 & - & & & 100 & [34] \\
\hline 1280 & 100 & 2 & - & - & 47 & - & & & 500 & \\
\hline 2300 & 210 & 8 & - & - & 40 & - & $1^{\mathrm{b}}$ & & 15 & {$[32]$} \\
\hline 430TOC & - & - & - & - & $51 \mathrm{TOC}$ & - & $0.1^{\mathrm{a}}$ & & 300 & [35] \\
\hline 26,000 & 2920 & 7.8 & - & 63 & 0.32 & - & $3.5^{\mathrm{b}}$ & & 1500 & {$[36]$} \\
\hline 26,000 & 2920 & 7.8 & - & 61 & 0.35 & - & $4.7^{\mathrm{b}}$ & & 1500 & \\
\hline
\end{tabular}

The introduction of UV irradiation into the Fenton process as well as electro-Fenton process may be able to improve the removal of COD. Many researchers studied the treatment efficiency of Fenton, photo-Fenton and electro-Fenton processes and the performances are summarized in Table 4. It indicated that leachate quality in terms of COD, odor, and color can be greatly improved following Fenton treatment.

The treatment efficiency of Fenton process depends on $\mathrm{pH}$ and the dosage of $\mathrm{Fe}^{2+}$ and $\mathrm{H}_{2} \mathrm{O}$. According to Table 4, the optimal $\mathrm{pH}$ was in a range 2.0-4.0. The $\mathrm{pH}$ value affects the activity of both the oxidant and the substrate, the speciation of iron, and hydrogen peroxide decomposition [44]. Higher $\bullet \mathrm{OH}$ radical product yields in the $\mathrm{pH}$ range of $2.0-4.0$ by a reaction involving in the organometallic complex where either hydrogen peroxide is regenerated or reaction rates are increased [45]. The dosage of $\mathrm{Fe}^{2+}$ and $\mathrm{H}_{2} \mathrm{O}_{2}$ are major operational cost items for wastewater treatment. The removal of organic contaminants is improved as the concentration of $\mathrm{Fe}^{2+}$ and $\mathrm{H}_{2} \mathrm{O}_{2}$ increases. However, the extent of increase becomes negligible when the dosage is increased above a certain threshold level. Most researches indicated that the optimal molar ratio of $\mathrm{H}_{2} \mathrm{O}_{2}$ to $\mathrm{Fe}^{2+}$ was from 1.5 to 3.0 [44, 46-48].

Fenton process can significantly remove recalcitrant and toxic organic compounds, and increase the biodegradability of organic compounds $[49,50,52,56]$. There are four advantages of the Fenton's reagent: (i) both iron and hydrogen peroxide are relative cheap and nontoxic; (ii) there is no mass transfer limitation due to its homogeneous catalytic nature; (iii) there is no form of energy involved as catalyst; (iv) the process is technologically simple. However, Fenton process also shows drawback that large amounts of iron sludge may form, because $\mathrm{Fe}^{3+}$ is converted to ferric-hydroxo complexes.

2.3. Electrochemical Oxidation Processes. Electrochemical oxidation of pollutants in wastewater is fulfilled through two different approaches, as shown in Figure 1: indirect oxidation, where a mediator is electrochemically generated to carry out oxidation, and direct anodic oxidation, where pollutants are destroyed on the anode surface [57]. During indirect oxidation, the agents generated anodically, which are responsible for oxidation of inorganic and organic 
TABLE 4: Fenton, photo-Fenton, and electro-Fenton treatments of leachates.

\begin{tabular}{|c|c|c|c|c|c|c|}
\hline \multicolumn{3}{|c|}{ Initial characteristic of leachate } & \multirow{2}{*}{$\begin{array}{c}\text { COD } \\
\text { Removal (\%) }\end{array}$} & \multirow{2}{*}{$\begin{array}{c}\mathrm{BOD} / \mathrm{COD} \\
\text { after treatment }\end{array}$} & \multirow{2}{*}{ Optimal condition } & \multirow{2}{*}{ Reference } \\
\hline $\mathrm{COD}(\mathrm{mg} / \mathrm{L})$ & $\mathrm{BOD}(\mathrm{mg} / \mathrm{L})$ & $\mathrm{pH}$ & & & & \\
\hline \multicolumn{7}{|c|}{ Fenton } \\
\hline 1300 & 30 & 8.7 & - & - & $\begin{array}{l}\mathrm{pH}: 3.5, \mathrm{Fe}_{2}\left(\mathrm{SO}_{4}\right)_{3}: 500 \mathrm{mg} / \mathrm{L}, \\
\mathrm{H}_{2} \mathrm{O}_{2}: 1650 \mathrm{mg} / \mathrm{L}\end{array}$ & {$[39]$} \\
\hline $8298-8894$ & - & $6.65-6.69$ & - & - & $\begin{array}{l}\mathrm{pH}: 2.5, \mathrm{H}_{2} \mathrm{O}_{2} / \mathrm{Fe}^{2+} \text { (molar ratio): } \\
1.5 \text {, reaction time: } 30 \text { min }\end{array}$ & {$[44]$} \\
\hline 10540 & 2300 & 8.2 & 60 & 0.5 & $\begin{array}{l}\mathrm{pH}: 3, \mathrm{Fe}^{2+}: 275 \mathrm{mg} / \mathrm{L}, \mathrm{H}_{2} \mathrm{O}_{2}: \\
3300 \mathrm{mg} / \mathrm{L} \text {, reaction time: } 2 \mathrm{~h}\end{array}$ & {$[49]$} \\
\hline $837-6119$ & $42.50-620.00$ & $8.09-8.47$ & $\begin{array}{c}80 \\
\text { (young leachate) } \\
60 \sim 70 \\
\text { (old leachate) }\end{array}$ & - & $\begin{array}{l}\mathrm{pH}: 2.5, \mathrm{H}_{2} \mathrm{O}_{2} / \mathrm{Fe}^{2+} \text { (molar ratio): } \\
\text { 1.5, }\left[\mathrm{H}_{2} \mathrm{O}_{2}\right]: 0.075 \mathrm{M}\end{array}$ & {$[46]$} \\
\hline $1100-1300$ & - & 8.18 & 61 & - & $\begin{array}{l}\mathrm{pH}: 3,\left[\mathrm{H}_{2} \mathrm{O}_{2}\right]: 0.24 \mathrm{M}, \\
\left.\mathrm{H}_{2} \mathrm{O}_{2} / \mathrm{Fe}^{2+} \text { (molar ratio }\right): 3\end{array}$ & {$[47]$} \\
\hline 8894 & - & $6.65-6.69$ & 89 & - & $\begin{array}{l}\text { pH: } 2.5,\left[\mathrm{H}_{2} \mathrm{O}_{2}\right]: 0.15 \mathrm{M}, \mathrm{H}_{2} \mathrm{O}_{2} / \mathrm{Fe}^{2+} \\
\text { (molar ratio): } 3\end{array}$ & {$[48]$} \\
\hline $5700 \pm 300$ & $3600 \pm 200$ & $7.8 \pm 0.3$ & 66 & 0.88 & $\begin{array}{l}\mathrm{pH}: 3.5, \mathrm{H}_{2} \mathrm{O}_{2}: 650 \mathrm{mg} / \mathrm{L}, \\
\mathrm{H}_{2} \mathrm{O}_{2} / \mathrm{Fe}^{2+} \text { (molar ratio): } 1: 19\end{array}$ & {$[50]$} \\
\hline \multicolumn{7}{|c|}{ Photo-Fenton } \\
\hline 3824 & 680 & 7.94 & 86 & - & $\mathrm{Fe}^{2+}: 2000 \mathrm{mg} / \mathrm{L}, \mathrm{H}_{2} \mathrm{O}_{2}: 10000 \mathrm{mg} / \mathrm{L}$ & {$[51]$} \\
\hline $5200 \pm 27$ & $720 \pm 81$ & $8.4 \pm 0.1$ & 49 & 0.4 & $\begin{array}{l}\mathrm{pH}: 2.8, \mathrm{Fe}^{2+}: 10 \mathrm{mg} / \mathrm{L}, \mathrm{H}_{2} \mathrm{O}_{2}: \\
2000 \mathrm{mg} / \mathrm{L}\end{array}$ & {$[52]$} \\
\hline 1150 & 4.6 & & 70 & & $\begin{array}{l}\mathrm{pH}: 3, \mathrm{Fe}^{2+}: 56 \mathrm{mg} / \mathrm{L}, \mathrm{H}_{2} \mathrm{O}_{2}: \\
34 \mathrm{mg} / \mathrm{L}, \mathrm{UV}: 80 \mathrm{KW} / \mathrm{m}^{3}\end{array}$ & {$[53]$} \\
\hline \multicolumn{7}{|c|}{ Electro-Fenton } \\
\hline 5000 & - & 6.4 & 83.4 & - & $\begin{array}{l}\text { pH: } 3, \mathrm{H}_{2} \mathrm{O}_{2}: 0.34 \mathrm{~mol} / \mathrm{L}, \mathrm{Fe}^{2+}: \\
0.038 \mathrm{~mol} / \mathrm{L}, \mathrm{I}: 2 \mathrm{~A}, \mathrm{~d}=2.1 \mathrm{~cm}\end{array}$ & {$[54]$} \\
\hline 2350 & - & 2.36 & 72 & - & $\begin{array}{l}\mathrm{pH}: 3, \mathrm{H}_{2} \mathrm{O}_{2}: 2000 \mathrm{mg} / \mathrm{L}, \mathrm{I}: 2 \mathrm{~A} \text {, } \\
\text { reaction time: } 20 \mathrm{~min}\end{array}$ & {$[55]$} \\
\hline 1941 & 195 & 8.1 & 69 & 0.29 & $\mathrm{pH}: 4, \mathrm{H}_{2} \mathrm{O}_{2}: 750 \mathrm{mg} / \mathrm{L}$ & {$[56]$} \\
\hline
\end{tabular}

pollutants may be chlorine and hypochlorite, hydrogen peroxide, ozone and metal mediators such as $\mathrm{Ag}^{2+}$. Direct anodic oxidation is achieved through two different pathways: electrochemical conversion and electrochemical combustion [58]. During electrolysis, two species of active oxygen can be electrochemically generated on oxide anodes $\left(\mathrm{MO}_{x}\right)$. One is the chemisorbed "active oxygen" (oxygen in the oxide lattice, $\left.\mathrm{MO}_{x+1}\right)$, responsible for the electrochemical conversion through (15). While the other is the physisorbed "active oxygen" (adsorbed hydroxyl radicals, $\bullet \mathrm{OH}$ ), responsible for electrochemical combustion through (16):

$$
\begin{gathered}
\mathrm{R}+\mathrm{MO}_{x+1} \longrightarrow \mathrm{RO}+\mathrm{MO}_{x}, \\
\mathrm{R}+\mathrm{MO}_{x}(\bullet \mathrm{OH})_{z} \longrightarrow \mathrm{CO}_{2}+z \mathrm{H}^{+}+z \mathrm{e}+\mathrm{MO}_{x},
\end{gathered}
$$

where $\mathrm{R}$ represents organic compounds; $z$ represents the number of absorbed $\bullet \mathrm{OH}$ on anode.

During the electrochemical oxidation of landfill leachate, the removal of pollutants may be primarily attributed to indirect oxidation, utilizing chlorine/hypochlorite formed by anodic oxidation of chlorine originally existing or added in the leachate [59]. However, direct anodic oxidation may to some extent destroy pollutants adsorbed on the anode surface [60]. A series of reactions involving indirect oxidation during electro-oxidation are shown in (17)-(23)

Anodic reactions : $2 \mathrm{Cl}^{-} \longrightarrow \mathrm{Cl}_{2}+2 \mathrm{e}^{-}$,

$6 \mathrm{HOCl}+3 \mathrm{H}_{2} \mathrm{O} \longrightarrow 2 \mathrm{ClO}_{3}^{-}+4 \mathrm{Cl}^{-}+12 \mathrm{H}^{+}+1.5 \mathrm{O}_{2}+6 \mathrm{e}^{-}$,

$$
2 \mathrm{H}_{2} \mathrm{O} \longrightarrow \mathrm{O}_{2}+4 \mathrm{H}^{+}+4 \mathrm{e}^{-},
$$

Bulk reactions : $\mathrm{Cl}_{2}+\mathrm{H}_{2} \mathrm{O} \longrightarrow \mathrm{HOCl}+\mathrm{H}^{+}+\mathrm{Cl}^{-}$,

$$
\mathrm{HOCl} \longrightarrow \mathrm{H}^{+}+\mathrm{OCl}^{-}
$$

Cathodic reactions : $2 \mathrm{H}_{2} \mathrm{O}+2 \mathrm{e}^{-} \longrightarrow 2 \mathrm{OH}^{-}+\mathrm{H}_{2}$,

$$
\mathrm{OCl}^{-}+\mathrm{H}_{2} \mathrm{O}+2 \mathrm{e}^{-} \longrightarrow \mathrm{Cl}^{-}+2 \mathrm{OH}^{-} .
$$




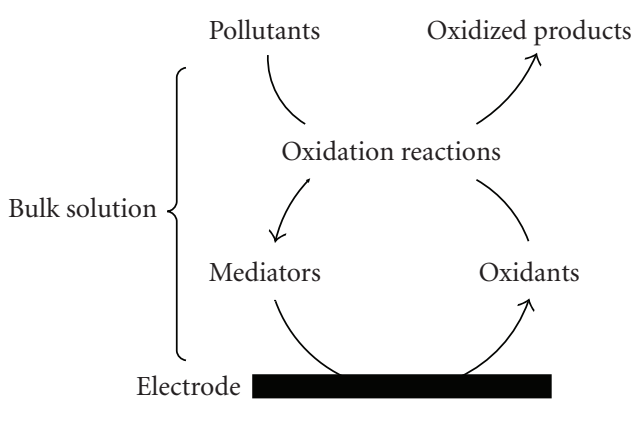

Indirect oxidation

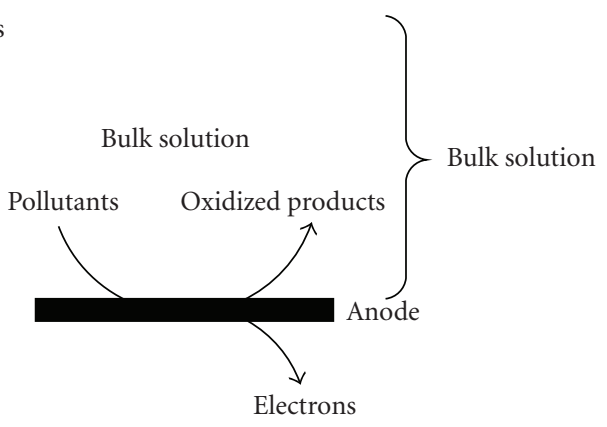

Direct oxidation

FIGURE 1: Pollutant removal pathways in electrochemical oxidation (indirect and direct oxidation) [57].

Hypochlorite $\left(\mathrm{OCl}^{-}\right)$generated in (20) and (21) is a strong oxidant that can oxidize aqueous organic compounds. So, it can oxidize the organic matters in the leachate.

Some researchers have investigated the treatment efficiency of electrochemical oxidation in treating landfill leachate [59-63]. The pollutant removal efficiency was influenced by a number of operating factors, including anode materials, $\mathrm{pH}$, current density, $\mathrm{Cl}^{-}$concentration, and electrolytes added (Table 5). The common anode materials are ternary Sn-Pd-Ru oxidecoated titanium (SPR), binary oxidecoated titanium $\mathrm{Ru}$-Ti oxide (DSA), $\mathrm{PbO}_{2}$-coated titanium $\left(\mathrm{PbO}_{2} / \mathrm{Ti}\right)$, graphite, $\mathrm{SnO}_{2}$-coated titanium $\left(\mathrm{SnO}_{2} / \mathrm{Ti}\right)$, iron $(\mathrm{Fe})$ and aluminum $(\mathrm{Al})$, and the $\mathrm{COD}$ removal efficiency when using the anode material followed the order of SPR $>\mathrm{DSA}>\mathrm{PbO}_{2} / \mathrm{Ti}>$ graphite [59]. Moraes and Bertazzoli [61] found that the removal rates achieved were $73 \%$ for COD, $57 \%$ for TOC, $86 \%$ for color and $49 \%$ for ammonium at a current density of $116.0 \mathrm{~mA} / \mathrm{cm}^{2}$, using oxide-coated titanium anode. Bashir et al. [63] used graphite carbon and got $70 \%$ BOD removal, $68 \%$ COD removal, and $84 \%$ color removal when the current density was $79.9 \mathrm{~mA} / \mathrm{cm}^{2}$ and reaction time was 2 hours.

Electrochemical oxidation of landfill leachate under appropriate conditions can remove most COD and significantly remove color. The important advantage of electrochemical oxidization is to oxidize organic pollutants into $\mathrm{CO}_{2}$ and water to avoid a problem of contaminants shifting from one phase to another. Also, the operation at room temperature and atmospheric pressure prevents volatilization and discharge of unreacted wastes, and the reaction can be simply terminated in seconds by cutting o the power [64]. However, there are two drawbacks of electrooxidation which may limit its wide application for landfill leachate treatment, one is high energy consumption, and the other is potential for formation of chlorinated organics. Especially because of its expensive operating costs compared with other available technologies (for example, biological processes), electro-oxidation will be favored as a finishing step in a combined process or an auxiliary unit in emergency situations, instead of a full treatment for landfill leachate [65].

2.4. Other AOP Processes. Wet air oxidation (WAO) is a useful treatment method for reduction of aqueous pollution bound to heavily contaminated wastewater, in particular when it is necessary to treat low volumes. This process consists in the oxidation of dissolved or suspended aqueous solution of organic and inorganic substances by means of oxygen, at elevated temperature $(450-590 \mathrm{~K})$ and pressure (2-15 MPa), assuring wet conditions of reaction. Under these conditions organic waste streams too dilute to incinerate and too concentrated for biological treatment can be degraded to simpler, frequently more biodegradable, organic compounds or completely converted to $\mathrm{CO}_{2}$ and $\mathrm{H}_{2} \mathrm{O}$ [66]. Typically, WAO process has shown promising results $(80 \%-99 \%$ of COD removal) for a complete mineralization of organic compounds or for their degradation into a less complex structure, which is more biodegradable [67]. This process is cost-effective for leachate treatment with COD concentrations ranging from 10,000 to $100,000 \mathrm{mg} / \mathrm{L}$. If complete COD removal is not required, the operating conditions such as the air flow rate, temperature, and pressure can be lowered to reduce the operational cost [68]. Although WAO offers some advantages such as a small plant for operations and its ability to deal with varying flow rates and composition of the effluent, this process is not cost-effective for leachate treatment with a COD concentration of less than $5000 \mathrm{mg} / \mathrm{L}$.

Ultrasonic process is considered as a possibility in wastewater treatment for several decades. It is able to remove pollutants through the production of radicals in the bubble of cavitation that can react with refractory compounds [69]. Ultrasonic irradiation is an effective method for the removal of organic matters and ammonia nitrogen from landfill leachate. After 180 minutes ultrasound irradiation (ultrasonic power input: $150 \mathrm{~W}, \mathrm{pH}$ : 11 ) up to $96 \%$ ammonia nitrogen removal efficiency can be obtained [70]. Due to the high cost of ultrasonic, it is always used as preor posttreatment of the biological treatment. Ultrasound pretreatment of raw leachate can significantly improve the removal rates of COD and nitrogen compound (frequency: $20 \mathrm{kHz}$ and amplitude: $12 \mu \mathrm{m}$ ) [71].

It is obvious that WAO and ultrasonic show a better treatment efficiency of the landfill leachate. However, there are two drawbacks of the two AOPs. One is high energy consumption, and the other is the operation mode restrain its practical application. They are suitable for small quantity and high strength wastewater. 
TABLE 5: Influence of operating factors in electro-oxidation of leachate [57].

\begin{tabular}{ll}
\hline Operating factor & Influence \\
\hline Anode materials & $\begin{array}{l}\text { Anode materials with high electrocatalytic activity and high anodic oxygen evolution potential cause a high } \\
\text { COD and } \mathrm{NH}_{3}-\mathrm{N} \text { removal efficiency; usage of metal anode such as } \mathrm{Fe} \text { and } \mathrm{Al} \text { causes simultaneous } \\
\text { electro-oxidation and electro-coagulation }\end{array}$ \\
$\mathrm{pH}$ & $\begin{array}{l}\text { The influence of } \mathrm{pH} \text { is unclear. Reported results are inconsistent } \\
\text { Increase in current density causes increase in removal efficiencies of COD and color }\end{array}$ \\
$\begin{array}{l}\text { Current density } \\
\text { chloride ion }\end{array}$ & $\begin{array}{l}\text { Increase in } \mathrm{Cl}^{-} \text {concentration improves removal of pollutants, but increase the hazard of formation of } \\
\text { chlorinated organics }\end{array}$ \\
$\begin{array}{l}\text { Additional } \\
\text { electrolytes }\end{array}$ & Eects of additional electrolytes depend on their species and properties \\
\hline
\end{tabular}

TABLE 6: Summary of the highest reported COD removal of some AOPs.

\begin{tabular}{|c|c|c|c|c|}
\hline AOPs & Optimal condition & $\begin{array}{l}\text { Initial COD } \\
(\mathrm{mg} / \mathrm{L})\end{array}$ & $\begin{array}{l}\text { COD removal efficiency } \\
(\%)\end{array}$ & Reference \\
\hline $\mathrm{O}_{3}$ & $3 \mathrm{~g} / \mathrm{L}$ & 3460 & 48 & {$[24]$} \\
\hline $\mathrm{O}_{3} / \mathrm{H}_{2} \mathrm{O}_{2}$ & $\mathrm{O}_{3}: 3.5 \mathrm{~g} / \mathrm{gCOD} \mathrm{H}_{2} \mathrm{O}_{2} \mathrm{~g} / \mathrm{g} \mathrm{O}_{3}$ & 2000 & 95 & {$[28]$} \\
\hline $\mathrm{O}_{3} / \mathrm{UV}$ & $\mathrm{O}_{3}: 3.5 \mathrm{~g} / \mathrm{gCODUV}: 1500 \mathrm{~W}$ & 26,000 & 63 & {$[36]$} \\
\hline Fenton & pH: $2.5,\left[\mathrm{H}_{2} \mathrm{O}_{2}\right]: 0.15 \mathrm{M}, \mathrm{H}_{2} \mathrm{O}_{2} / \mathrm{Fe}^{2+}$ (molar ratio): 3 & 8894 & 89 & {$[48]$} \\
\hline Photo-Fenton & $\mathrm{Fe}^{2+}: 2000 \mathrm{mg} / \mathrm{L}, \mathrm{H}_{2} \mathrm{O}_{2}: 10000 \mathrm{mg} / \mathrm{L}$ & 3823.8 & 86 & {$[51]$} \\
\hline Electro-Fenton & $\begin{array}{l}\mathrm{pH}: 3, \mathrm{H}_{2} \mathrm{O}_{2}: 0.34 \mathrm{~mol} / \mathrm{L}, \mathrm{Fe}^{2+}: 0.038 \mathrm{~mol} / \mathrm{L}, \mathrm{I}: 2 \mathrm{~A}, \mathrm{~d}= \\
2.1 \mathrm{~cm}\end{array}$ & 5000 & 83 & {$[54]$} \\
\hline $\begin{array}{l}\text { Electrochemical } \\
\text { oxidation }\end{array}$ & Current density: $116.0 \mathrm{~mA} / \mathrm{cm}^{2}$ & 1855 & 73 & {$[61]$} \\
\hline
\end{tabular}

\section{Comparison of Various AOP's Performance}

The outcomes of AOPs applied to treat the landfill leachate can be classified into two types: (i) oxidize organics substances to their highest stable oxidation states being carbon dioxide and water (i.e., to reach complete mineralization); (ii) improve the biodegradability of recalcitrant organic pollutants up to a value compatible with subsequent economical biological treatment. Thus, the comparison of various AOP's performance was evaluated from these two aspects.

Table 6 presents the outstanding treatment performance and optimum operate condition of various AOPs for COD removal from landfill leachate. The ozone-based process can achieve $40-95 \%$ of COD removal with COD concentration ranging from 2000 to $26,000 \mathrm{mg} / \mathrm{L}$, while electrochemical oxidation process and Fenton process can achieve 70-90\% of COD removal with COD concentration ranging from 1855 to $8894 \mathrm{mg} / \mathrm{L}$. It should be noted that the treatment efficiency of Fenton process is better than ozone-based process and electrochemical oxidation. In term of biodegradability improvement, BOD/COD ratios are 0.29-0.88 [49, 50, 52, 56] and $0.1-0.5$ (Table 3 ) were reported after oxidation by Fenton process and ozone-based oxidation, respectively.

Concerning the cost of various AOPs, electrochemical oxidation, wet air oxidation, and ultrasound oxidation are more expensive due to the high demand of electrical energy for devices ozonizers, UV lamps, ultrasounds. The only exception is the Fenton's process. In such a process, in fact, under acidic condition, a Fe ${ }^{2+} / \mathrm{H}_{2} \mathrm{O}_{2}$ mixture produces - $\mathrm{OH}$ radicals in a very effective way [49]. Tizaoui et al. [27] estimated the treatment cost of $\mathrm{O}_{3} / \mathrm{H}_{2} \mathrm{O}_{2}$ system was about 2.3 US\$/kg COD. Kurniawan et al. [17] showed that the treatment coat of leachate using ozone-GAC adsorption varies between US\$2 and 4 per $\mathrm{m}^{3}$ of the treatment effluent. While Rivas et al. [72] estimated the operational cost for Fenton treatment of leachate was $8.0 \times 10^{-3}$ US $\$$ per $\mathrm{m}^{3}$ of leachate and ppm of COD removed. Based on the analysis and Lopez et al. [49], Fenton process seems to be the best compromise because the process is technologically simple, there is no mass transfer limitation (homogeneous mature) and both iron and hydrogen peroxide are relatively cheap and nontoxic. But Fenton's process required low $\mathrm{pH}$ and a modification of this parameter is necessary.

\section{Conclusions}

The application of AOPs including ozone-based oxidation, Fenton oxidation, electrochemical oxidation, wet air oxidation, and ultrasound oxidation to treatment of landfill leachate was reviewed. Among the AOPs reviewed, ozone-based oxidation and Fenton oxidation are the most frequently studied and widely applied methods for the 
treatment of landfill leachate. Both techniques can achieve about $15 \sim 95 \%$ of COD removal with COD concentration ranging from 600 to $26,000 \mathrm{mg} / \mathrm{L}$. In particular, Fenton process can improve BOD/COD ratio to close 0.5 . Fenton process seems to be the best compromise because the process is technologically simple, there is no mass transfer limitation (homogeneous mature) and both iron and hydrogen peroxide are cheap and nontoxic. From the economic point of view, using Fenton process as the pretreatment of biological treatment can lower the cost and improve the treatment efficiency.

In the past, most of works were focused on the removal efficiency of organic matters from landfill leachate. Only a few researches considering the toxicity reduction were involved. However, the toxicity assessment of landfill leachate is very important, which determines the effect of the subsequent biological treatment or the influence on the environment. So, the toxicity reduction of AOPs should be evaluated in the future research.

\section{References}

[1] T. A. Kurniawan, W.-H. Lo, and G. Y. S. Chan, "Physicochemical treatments for removal of recalcitrant contaminants from landfill leachate," Journal of Hazardous Materials, vol. 129, no. 1-3, pp. 80-100, 2006.

[2] S. Renou, J. G. Givaudan, S. Poulain, F. Dirassouyan, and P. Moulin, "Landfill leachate treatment: review and opportunity," Journal of Hazardous Materials, vol. 150, no. 3, pp. 468493, 2008.

[3] H. Alvarez-Vazquez, B. Jefferson, and S. J. Judd, "Membrane bioreactors vs conventional biological treatment of landfill leachate: a brief review," Journal of Chemical Technology and Biotechnology, vol. 79, no. 10, pp. 1043-1049, 2004.

[4] E. S. K. Chian and P. B. DeWalle, "Sanitary landfill leachates and their leachate treatment," Journal of the Environmental Engineering Division, vol. 102, no. 2, pp. 411-431, 1976.

[5] K. Y. Foo and B. H. Hameed, "An overview of landfill leachate treatment via activated carbon adsorption process," Journal of Hazardous Materials, vol. 171, no. 1-3, pp. 54-60, 2009.

[6] F. J. Rivas, F. Beltrán, F. Carvalho, B. Acedo, and O. Gimeno, "Stabilized leachates: sequential coagulation-flocculation + chemical oxidation process," Journal of Hazardous Materials, vol. 116, no. 1-2, pp. 95-102, 2004.

[7] C. Bernard, J. R. Colin, and L. D.-D. Anne, "Estimation of the hazard of landfills through toxicity testing of leachates. Comparison of physico-chemical characteristics of landfill leachates with their toxicity determined with a battery of tests," Chemosphere, vol. 35, no. 11, pp. 2783-2796, 1997.

[8] S. K. Marttinen, R. H. Kettunen, K. M. Sormunen, R. M. Soimasuo, and J. A. Rintala, "Screening of physical-chemical methods for removal of organic material, nitrogen and toxicity from low strength landfill leachates," Chemosphere, vol. 46, no. 6, pp. 851-858, 2002.

[9] M. Pirbazari, V. Ravindran, B. N. Badriyha, and S.-H. Kim, "Hybrid membrane filtration process for leachate treatment," Water Research, vol. 30, no. 11, pp. 2691-2706, 1996.

[10] C. L. S. Sisinno, E. C. Oliveira-Filho, M. C. Dufrayer, J. C. Moreira, and F. J. R. Paumgartten, "Toxicity evaluation of a municipal dump leachate using zebrafish acute tests," Bulletin of Environmental Contamination and Toxicology, vol. 64, no. 1, pp. 107-113, 2000.
[11] Y. Deng and J. D. Englehardt, "Electrochemical oxidation for landfill leachate treatment," Waste Management, vol. 27, no. 3, pp. 380-388, 2007.

[12] J. J. Wu, C.-C. Wu, H.-W. Ma, and C.-C. Chang, "Treatment of landfill leachate by ozone-based advanced oxidation processes," Chemosphere, vol. 54, no. 7, pp. 997-1003, 2004.

[13] S. A. Parsons and M. Williams, "Introduction," in Advanced Oxidation Processes for Water and Wastewater Treatment, S. A. Parsons, Ed., pp. 1-6, IWA Publishing, London, UK, 2004.

[14] A. Al-Kdasi, A. Idris, K. Saed, and C. T. Guan, "Treatment of textile wastewater by advanced oxidation processes-a review," Global Nest, vol. 6, no. 3, pp. 226-234, 2004.

[15] C. A. Murray and S. A. Parsons, "Advanced oxidation processes: flowsheet options for bulk natural organic matter removal," Water Science and Technology, vol. 4, no. 4, pp. 113119, 2004.

[16] D. M. Bila, A. F. Montalvao, A. C. Silva, and M. Dezotti, "Ozonation of a landfill leachate: evaluation of toxicity removal and biodegradability improvement," Journal of Hazardous Materials, vol. 117, no. 2-3, pp. 235-242, 2005.

[17] T. A. Kurniawan, W.-H. Lo, and G. Y. S. Chan, "Radicalscatalyzed oxidation reactions for degradation of recalcitrant compounds from landfill leachate," Chemical Engineering Journal, vol. 125, no. 1, pp. 35-57, 2006.

[18] U. Von Gunten, "Ozonation of drinking water-part I. Oxidation kinetics and product formation," Water Research, vol. 37, no. 7, pp. 1443-1467, 2003.

[19] K. Ikehata and M. G. El-Din, "Degradation of recalcitrant surfactants in wastewater by ozonation and advanced oxidation processes: a review," Ozone: Science and Engineering, vol. 26, no. 4, pp. 327-343, 2004.

[20] X. Ntampou, A. I. Zouboulis, and P. Samaras, "Appropriate combination of physico-chemical methods (coagulation/flocculation and ozonation) for the efficient treatment of landfill leachates," Chemosphere, vol. 62, no. 5, pp. 722-730, 2006.

[21] R. Tosik, "Dyes color removal by ozone and hydrogen peroxide: some aspects and problems," Ozone, vol. 27, no. 4, pp. 265-271, 2005.

[22] G. R. Peyton and W. H. Glaze, "Destruction of pollutants in water with ozone in combination with ultraviolet radiation. 3. Photolysis of aqueous ozone," Environmental Science and Technology, vol. 22, no. 7, pp. 761-767, 1988.

[23] N. H. Ince, "Light-enhanced chemical oxidation for tertiary treatment of municipal landfill leachate," Water Environment Research, vol. 70, no. 6, pp. 1161-1169, 1998.

[24] A. C. Silva, M. Dezotti, and G. L. Sant'Anna Jr., “Treatment and detoxification of a sanitary landfill leachate," Chemosphere, vol. 55, no. 2, pp. 207-214, 2004.

[25] F. J. Rivas, F. Beltrán, O. Gimeno, B. Acedo, and F. Carvalho, "Stabilized leachates: ozone-activated carbon treatment and kinetics," Water Research, vol. 37, no. 20, pp. 4823-4834, 2003.

[26] I. Monje-Ramirez and M. T. O. D. Velásquez, "Removal and transformation of recalcitrant organic matter from stabilized saline landfill leachates by coagulation-ozonation coupling processes," Water Research, vol. 38, no. 9, pp. 2358-2366, 2004.

[27] C. Tizaoui, L. Bouselmi, L. Mansouri, and A. Ghrabi, "Landfill leachate treatment with ozone and ozone/hydrogen peroxide systems," Journal of Hazardous Materials, vol. 140, no. 1-2, pp. 316-324, 2007. 
[28] O. Wable, M. Jousset, P. Courant, and J. P. Duguet, "Oxidation of landfill leachates by ozone and hydrogen peroxide: a French example," in Proceedings of the International Symposium on Ozone-Oxidation Methods for Water and Wastewater treatment, Berlin, Germany, 1993.

[29] C. D. Iaconi, R. Ramadori, and A. Lopez, "Combined biological and chemical degradation for treating a mature municipal landfill leachate," Biochemical Engineering Journal, vol. 31, no. 2, pp. 118-124, 2006.

[30] P. Schulte, A. Bayer, F. Kuhn, T. Luy, and M. Volkmer, " $\mathrm{H}_{2} \mathrm{O}_{2} / \mathrm{O}_{2}, \mathrm{H}_{2} \mathrm{O}_{2} / \mathrm{UV}$ and $\mathrm{H}_{2} \mathrm{O}_{2} / \mathrm{Fe}^{2+}$ processes for the oxidation of hazardous wastes," Ozone Science and Engineering, vol. 17, pp. 119-134, 1995.

[31] D. Geenens, B. Bixio, and C. Thoeye, "Advanced oxidation treatment of landfill leachate," in Proceedings of the 7th InternationalWaste Management and Landfill Symposium, Sardinia, Italy, 1999.

[32] V. Bigot, F. Luck, H. Paillard, and A. Wagner, "Landfill leachate treatment: comparison of three oxidation processes using ozone," in Proceedings of the International Ozone Association Regional Conference, Zürich, Switzerland, 1994.

[33] P. Haapea, S. Korhonen, and T. Tuhkanen, "Treatment of industrial landfill leachates by chemical and biological methods: ozonation, ozonation + hydrogen peroxide, hydrogen peroxide and biological post-treatment for ozonated water," Ozone, vol. 24, no. 5, pp. 369-378, 2002.

[34] N. H. Ince, "Light-enhanced chemical oxidation for tertiary treatment of municipal landfill leachate," Water Environment Research, vol. 70, no. 6, pp. 1161-1169, 1998.

[35] A. Wenzel, A. Gahr, and R. Niessner, "TOC-removal and degradation of pollutants in leachate using a thin-film photoreactor," Water Research, vol. 33, no. 4, pp. 937-946, 1999.

[36] T. I. Qureshi, H.-T. Kim, and Y.-J. Kim, "UV-catalytic treatment of municipal solid-waste landfill leachate with hydrogen peroxide and ozone oxidation," Chinese Journal of Chemical Engineering, vol. 10, no. 4, pp. 444-449, 2002.

[37] J. D. Englehardt, Y. Deng, D. Meeroff, Y. Legrenzi, J. Mognol, and J. Polar, "Options for managing municipal landfill leachate: year 1 development of iron-mediated treatment processes," Tech. Rep., Florida Center for Solid and Hazardous Waste Management, 2006.

[38] Y. Deng and J. D. Englehardt, "Treatment of landfill leachate by the Fenton process," Water Research, vol. 40, no. 20, pp. 36833694, 2006.

[39] Y. W. Kang and K.-Y. Hwang, "Effects of reaction conditions on the oxidation efficiency in the Fenton process," Water Research, vol. 34, no. 10, pp. 2786-2790, 2000.

[40] W. Z. Tang, Physicochemical Treatment of Hazardous Wastes, Lewis Publishers, Boca Raton, Fla, USA, 2003.

[41] E. Neyens and J. Baeyens, "A review of classic Fenton's peroxidation as an advanced oxidation technique," Journal of Hazardous Materials, vol. 98, no. 1-3, pp. 33-50, 2003.

[42] P. Wang, I. W. C. Lau, H. H. P. Fang, and D. Zhou, "Landfill leachate treatment with combined UASB and fenton coagulation," Journal of Environmental Science and Health. Part A, vol. 35, no. 10, pp. 1981-1988, 2000.

[43] I. W. C. Lau, P. Wang, and H. H. P. Fang, "Organic removal of anaerobically treated leachate by Fenton coagulation," Journal of Environmental Engineering, vol. 127, no. 7, pp. 666-669, 2001.

[44] H. Zhang, J. C. Heung, and C.-P. Huang, "Optimization of Fenton process for the treatment of landfill leachate," Journal of Hazardous Materials, vol. 125, no. 1-3, pp. 166-174, 2005.
[45] D. L. Sedlak and A. W. Andren, "Oxidation of chlorobenzene with Fenton's reagent," Environmental Science and Technology, vol. 25, no. 4, pp. 777-782, 1991.

[46] D. Hermosilla, M. Cortijo, and C. P. Huang, "Optimizing the treatment of landfill leachate by conventional Fenton and photo-Fenton processes," Science of the Total Environment, vol. 407, no. 11, pp. 3473-3481, 2009.

[47] Y. Deng, "Physical and oxidative removal of organics during Fenton treatment of mature municipal landfill leachate," Journal of Hazardous Materials, vol. 146, no. 1-2, pp. 334-340, 2007.

[48] H. Zhang, H. J. Choi, and C.-P. Huang, "Treatment of landfill leachate by Fenton's reagent in a continuous stirred tank reactor," Journal of Hazardous Materials B, vol. 136, no. 3, pp. 618-623, 2006.

[49] A. Lopez, M. Pagano, A. Volpe, and A. C. Di Pinto, "Fenton's pre-treatment of mature landfill leachate," Chemosphere, vol. 54, no. 7, pp. 1005-1010, 2004.

[50] J. Kochany and E. Lipczynska-Kochany, "Utilization of landfill leachate parameters for pretreatment by Fenton reaction and struvite precipitation-a comparative study," Journal of Hazardous Materials, vol. 166, no. 1, pp. 248-254, 2009.

[51] O. Primo, M. J. Rivero, and I. Ortiz, "Photo-Fenton process as an efficient alternative to the treatment of landfill leachates," Journal of Hazardous Materials, vol. 153, no. 1-2, pp. 834-842, 2008.

[52] J. L. De Morais and P. P. Zamora, "Use of advanced oxidation processes to improve the biodegradability of mature landfill leachates," Journal of Hazardous Materials, vol. 123, no. 1-3, pp. 181-186, 2005.

[53] S.-M. Kim, S.-U. Geissen, and A. Vogelpohl, "Landfill leachate treatment by a photoassisted Fenton reaction," Water Science and Technology, vol. 35, no. 4, pp. 239-248, 1997.

[54] H. Zhang, D. Zhang, and J. Zhou, "Removal of COD from landfill leachate by electro-Fenton method," Journal of Hazardous Materials, vol. 135, no. 1-3, pp. 106-111, 2006.

[55] E. Atmaca, "Treatment of landfill leachate by using electroFenton method," Journal of Hazardous Materials, vol. 163, no. 1, pp. 109-114, 2009.

[56] S. H. Lin and C. C. Chang, "Treatment of landfill leachate by combined electro-Fenton oxidation and sequencing batch reactor method," Water Research, vol. 34, no. 17, pp. 42434249, 2000.

[57] Y. Deng and J. D. Englehardt, "Electrochemical oxidation for landfill leachate treatment," Waste Management, vol. 27, no. 3, pp. 380-388, 2007.

[58] C. Comninellis, "Electrocatalysis in the electrochemical conversion/combustion of organic pollutants for waste water treatment," Electrochimica Acta, vol. 39, no. 11-12, pp. 18571862, 1994.

[59] L.-C. Chiang, J.-E. Chang, and T.-C. Wen, "Indirect oxidation effect in electrochemical oxidation treatment of landfill leachate," Water Research, vol. 29, no. 2, pp. 671-678, 1995.

[60] X. M. Li, M. Wang, Z. K. Jiao, and Z. Y. Chen, "Study on electrolytic oxidation for landfill leachate treatment," China Water \& Wastewater, vol. 17, no. 8, pp. 14-17, 2001.

[61] P. B. Moraes and R. Bertazzoli, "Electrodegradation of landfill leachate in a flow electrochemical reactor," Chemosphere, vol. 58 , no. 1, pp. 41-46, 2005.

[62] L. K. Patan, M. Lemon, B. Freeman, and J. D. Newman, "Electrochemical peroxidation of contaminated aqueous leachate," Journal of Applied Electrochemistry, vol. 39, pp. 2593-2596, 2009. 
[63] M. J.K. Bashir, M. H. Isa, S. R. M. Kutty, et al., "Landfill leachate treatment by electrochemical oxidation," Waste Management, vol. 29, no. 9, pp. 2534-2541, 2009.

[64] J. Grimm, D. Bessarabov, and R. Sanderson, "Review of electro-assisted methods for water purification," Desalination, vol. 115, no. 3, pp. 285-294, 1998.

[65] R. Cossu, A. M. Polcaro, M. C. Lavagnolo, M. Mascia, S. Palmas, and F. Renoldi, "Electrochemical treatment of landfill leachate: Oxidation at $\mathrm{Ti} / \mathrm{PbO}_{2}$ and $\mathrm{Ti} / \mathrm{SnO}_{2}$ anodes," Environmental Science and Technology, vol. 32, no. 22, pp. 3570-3573, 1998.

[66] D. Goi, C. De Leitenburg, G. Dolcetti, and A. Trovarelli, "COD and AOX abatement in catalytic wet oxidation of halogenated liquid wastes using $\mathrm{CeO}_{2}$-based catalysts," Journal of Alloys and Compounds, vol. 408-412, pp. 1136-1140, 2006.

[67] F. Avezzu, G. Bissolotti, and C. Collivignarelli, "Combination of wet oxidation and activated sludge treatment," in Landfilling of Waste: Leachate, T. H. Christensen, R. Cossu, and R. Stegmann, Eds., pp. 333-352, E \& FN SPON, London, UK, 1992.

[68] S. T. Kolaczkowski, P. Plucinski, F. J. Beltran, F. J. Rivas, and D. B. McLurgh, "Wet air oxidation: a review of process technologies and aspects in reactor design," Chemical Engineering Journal, vol. 73, no. 2, pp. 143-160, 1999.

[69] E. Gonze, N. Commenges, Y. Gonthier, and A. Bernis, "High frequency ultrasound as a pre- or a post-oxidation for paper mill wastewaters and landfill leachate treatment," Chemical Engineering Journal, vol. 92, no. 1-3, pp. 215-225, 2003.

[70] S. Wang, X. Wu, Y. Wang, Q. Li, and M. Tao, "Removal of organic matter and ammonia nitrogen from landfill leachate by ultrasound," Ultrasonics Sonochemistry, vol. 15, no. 6, pp. 933-937, 2008.

[71] E. Neczaj, E. Okoniewska, and M. Kacprzak, "Treatment of landfill leachate by sequencing batch reactor," Desalination, vol. 185, no. 1-3, pp. 357-362, 2005.

[72] F. J. Rivas, F. Beltrán, O. Gimeno, and F. Carvalho, "Fenton-like oxidation of landfill leachate," Journal of Environmental Science and Health. Part A, vol. 38, no. 2, pp. 371-379, 2003. 

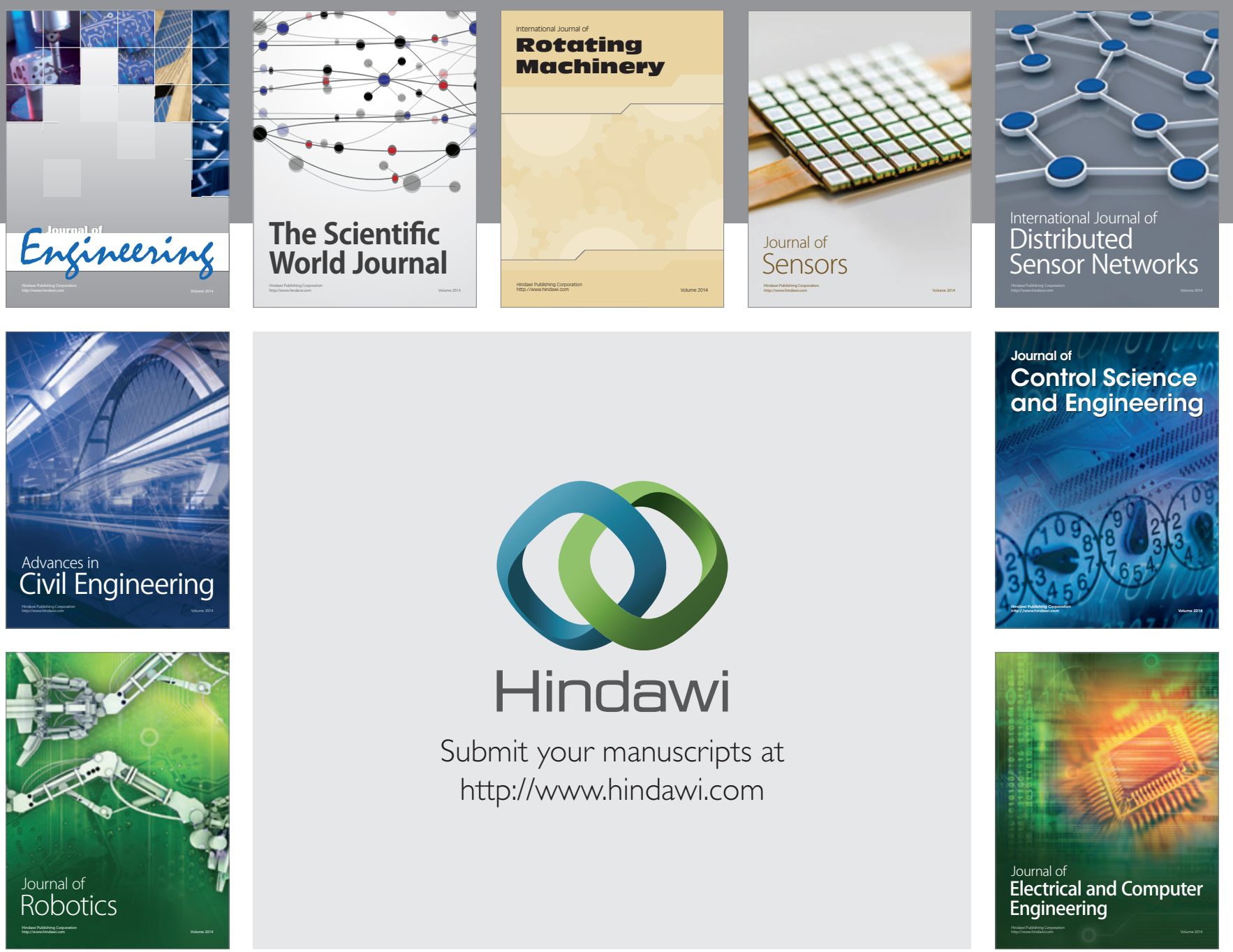

Submit your manuscripts at

http://www.hindawi.com
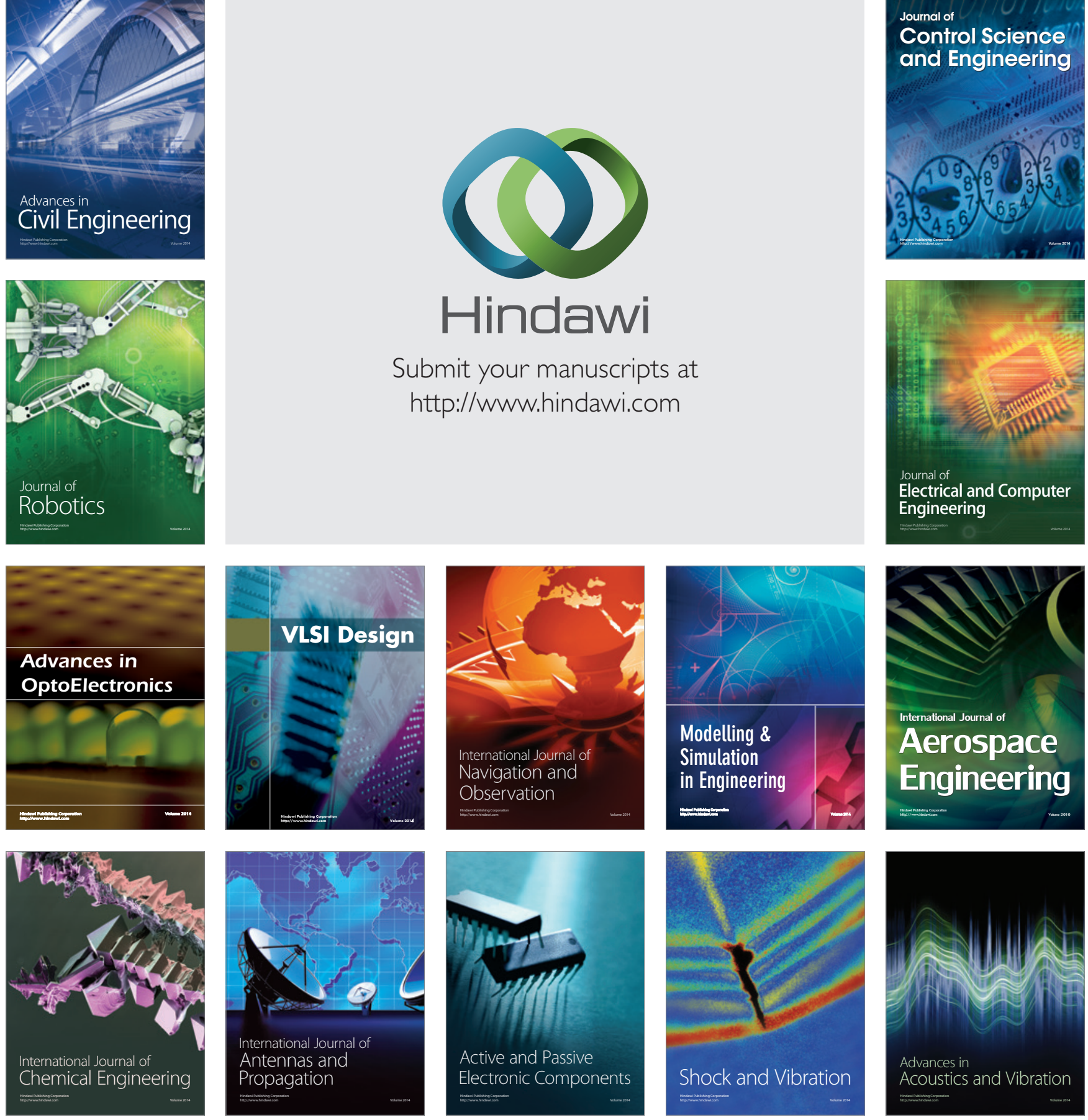